\title{
Ultra-Structural and Histochemical Analysis of Channel Catfish (Ictalurus punctatus) Liver Treated with Fumonisin $\mathbf{B}_{1}$
}

\author{
Rejane Maria Cirra Scaff ${ }^{1,2}$ and Vildes Maria Scussel ${ }^{1}$ * \\ ${ }^{1}$ Departamento de Morfologia; Centro de Ciências Biológicas; ${ }^{2}$ Departamento de Ciência e Tecnologia de \\ Alimentos; C.P.: 476; 88.040-900; vildes@cca.ufsc.br; Florianópolis - SC - Brasil.
}

\begin{abstract}
The histopathological effects of fumonisin $B_{1}\left(F B_{1}\right)$ injected intraperitoneally $(I P)$, was evaluated in catfish (Ictalurus punctatus). Fishes were divided into four Groups. Groups II, III and IV were treated IP with FB injections of 1; 5 and $10 \mathrm{mg} / \mathrm{kg}$ bw/day, respectively, during 21 days. At the $7^{\text {th }}, 14^{\text {th }}$ and $21^{\text {st }}$ day, fishes were sacrificed. The livers were hystologicaly analysed by the light and transmission electronic microscopy. Livers from the $7^{\text {th }}$ day showed organelles alterations, particularly in the granular endoplasmatic reticle, mitochondria, nucleus and nucleolus mediated by $F B_{1}$ doses. The occurrence of processes involved in the necrosis and apoptosis was detected. At the highest $F B_{1}$ dose, the livers presented an intense response with an accentuate tissue disorganization, absence of cell limits and intense cytoplasm vacuolization. The image analysis showed the occurrence of necrosis in some areas, characterized by fully broken or swollen cells. The apoptosis was observed as the cytoplasm contraction and the chromatin formed masses concentrated in the edge of the nucleus. There was strong evidence that the numerous hepatocytes in the liver from the fishes under the toxic dose of FBs were selectively removed by the apoptosis process.
\end{abstract}

Key words: Liver, catfish, fumonisin $\mathrm{B}_{1}$, histopathology, ultra-structural microscopy

\section{INTRODUCTION}

Fumonisins (FBs) are produced by the Fusarium species that contaminate especially the maize and derived products (Westhuizen et al., 2003; Nikiemg et al., 2004; Scaff \& Scussel, 2004; Domijan et al., 2005). They have been intensively studied in the current micotoxicology due to serious animal intoxication risk, as well as cancer promoting effects including in human. Their structure is similar to sphingosine and they block de novo sphingolipid biosynthesis through the sphinganine (sphingosine) inhibition $\mathrm{N}$ - acyltransferase (Wang et al., 1991). The consequence is the sphinganine intracellular accumulation, sphinganine / sphingosine elevation and depletion of sphingolipid complex (Tolleson et. al., 1999). Sphingolipids are the main components of the biological membranes, which play an important role including growth regulation, cell differentiation and proliferation (Lim et al., 1996). Fumonisin $\mathrm{B}_{1}\left(\mathrm{FB}_{1}\right)$ also affects the cellular regulation sites, apparently independent from the rupture mechanism of lipid metabolism. It results in cellular proliferation alteration, cell to cell communication, cellular adhesion and apoptosis, oxidative stress induction and gene expression modulation (Abado-Becognee et al., 1998; Tolleson et al., 1999; Mobio et al., 2000).

\footnotetext{
${ }^{*}$ Author for correspondence
} 
$\mathrm{FB}_{1}$ is associated with the equine leukoencephalomalacia (ELEM) and acute interstitial porcine pulmonary edema. Experiments have reported hepatoxicity in the horses, pigs and rats, hepatic cancer in the rats, nephropathy, immunological system depression and bone malformation among other disturbances in several animal species (Harrison, 1990; Gelderblom et al., 1991; Norred \& Voss, 1994; Scott, 1993; Howard et al., 1999; Bolger et al., 2001, Voss et al., 2002). More recently, Riley et al. (2004) reported that $\mathrm{FB}_{1}$ can induce neural tubes defect (NTD) in the mice.

Research on $\mathrm{FB}_{1}$ toxicity in the fishes is scarce, with some studies conducted particularly in the USA. Carps (Cyprinus carpio L.), when treated with $\mathrm{FB}_{1}$, presented pathological alterations in the parenchymal organs such as the liver, intestines, heart and kidney (Pepeljnjak et al., 2000). In a study carried out in catfish (Ictalurus punctatus) treated with corn feed contaminated with $F$. verticillioides $\left(20 \mathrm{mg} \mathrm{FB}_{1} / \mathrm{kg}\right.$ ), hepatic lesions and inhibition of fish development was observed (Lumlertdacha et al., 1995). Liver glycogen elevation, vacuolization increase in nervous fibers and brain perivascular linphohystiocitic invasion were observed in catfish treated with $F$. verticillioides culture containing $40 \mathrm{FB}_{1} / \mathrm{kg}$ ( $\mathrm{Li}$ et al., 1994). The sphingolipids in the catfish treated with the similar fungi culture presented a rate elevation of the sphinganine and sphingosine in the kidney, serum, liver and muscles (Goel et al. 1994). Channel catfish has been an important species both in commerce and sport not only in the USA, but in the last ten years, also in Brazil. Fresh water pisciculture has widely increased in the Southern Brazil and the most cultivated fishes are the American and African catfish. The $\mathrm{FB}_{1}$ has been detected in the fish feed and cases of the catfish poisoning have been reported in the southern Brazil during the summer leading to high mortality and economic losses (Scussel et al., 2004).

Taking into account scarce literature on the effect of $\mathrm{FB}_{1}$ in the subject in Brazil, a work was carried out to study the $\mathrm{FB}_{1}$ injected intraperitoneally (IP) [high absorption surface for the $\mathrm{FB}_{1}$ to be rapidly transferred into circulation enabling fast response at tissue / cell level] in order to evaluate the structural, ultra structural and histochemical alterations in the liver of the channel catfish.

\section{MATERIALS AND METHODS}

\section{Materials}

\section{Animals}

Male young channel catfish (60) weighing around $60 \mathrm{~g}$ from fish farms located in the Blumenau city in the state of Santa Catarina - Brazil, were used.

\section{Standard}

The $\mathrm{FB}_{1}$ was kindly donated by PROMEC, TygerSberg, South Africa.

\section{Reagents and Stains}

Comassie bright blue (BioRad); glutardialdehyde (Eletron Microscopic Sciences); paraphormaldehyde (Electron Microscopic Sciences); spurr resin (Electron Microscopic Sciences); sodium cacodilate (Electron Microscopic Sciences); osmium tetroxide (Polysciences); historesin glycolmetacrilate (LKB); hematoxylin, eosin (HE), Gomori tricromic, blue toluidin, Comassie brilliant blue, Schiff periodic acid (SPA), sudan black.

\section{Equipment}

Microtome (Reichert-Jung 4045), optical microscope (Olympus BH2) with camera (Olympus C-35-AD); ultra microtome (Porter Blum MT2 Sorvall); transmission electronic microscope (JEOL 100CX) wre used.

\section{Methods}

\section{FB $_{1}$ Treatment}

The fishes were divided randomly into four groups of 18 animals each and maintained in the Fish Research Laboratory Aquarium with air and continuous water flow $(1 \mathrm{~L} / \mathrm{min})$ at $25-28^{\circ} \mathrm{C}$ for $14 / 10 \mathrm{~h}$ light/dark cycles. Throughout the experiment, the water sanitation condition (oxygen, ammonia, $\mathrm{pH}$ ) was kept constant. The fish were fed with the balanced feed, previously analyzed for the mycotoxins (aflatoxins and $\mathrm{FB}_{\mathrm{s}}$ ), and showing nondetectable levels of mycotoxins. After 15 days of acclimatizing, three groups of the fishes were submitted to a daily IP $\mathrm{FB}_{1}$ injection treatment for 21 consecutive days, with 1,5 and 10 $\mathrm{mg} / \mathrm{kg} . \mathrm{bw} /$ day for Groups II, III, and IV, respectively, with saline solution as carrier. The Control Group (Group I) received only a saline 
solution IP. After $7^{\text {th }}, 14^{\text {th }}$ and $21^{\text {st }}$ days, 6 fishes of each group were sacrificed.

\section{Cat fish liver collection and fixation}

The fishes were anesthetized with $0.2 \mathrm{ml}$ Ketalar/Rompum mixture $(1: 1)$ and then a longitudinal incision in the ventral region was made with a bistoury blade, exposing the abdomen. The liver was removed and sectioned from 0.1 to 0.5 $\mathrm{mm}$ fragments, and immediately fixed at $4^{\circ} \mathrm{C}$ in $2.5 \%$ paraphormaldeyde for $2 \mathrm{~h}$ for subsequent hystological and photochemical analysis. For the ultra-structural analysis, the material was fixed in $2 \%$ glutaraldehyde for $2 \mathrm{~h}$.

\section{Light microscopy (LM)}

The tissue fragments sections of 5 to $7 \mu \mathrm{m}$, soaked in the glycolmetacrilate (historesin) and paraffin were prepared. The hystological staining techniques used were hematoxilyn-eosin (HE), toluidin blue and Gomori tricomic. The hystochemical methods for the total protein (comassie bright blue), carbohydrate (reaction to SPA - Schiff periodic acid) and lipids (Sudan black) were made according to Pearse (1985) and Brancoft et al. (1990).

\section{Transmission electronic microscopy (TEM)}

After the prior fixation, the liver fragments were post fixed in the osmium tetroxide $1 \%, \mathrm{pH} 7.2$ and soaked in spurr resine for $18 \mathrm{~h}$ at $70^{\circ} \mathrm{C}$. The ultra fine sections obtained in ultra-microtome, counterstained with uranile acetate $1 \%$ and Reynolds lead citrate, were analyzed and photographed in the transmission electronic microscope. The electron micrographies were obtained in Fuji film and revealed in Kodabromide RC-F4 paper.

\section{RESULTS AND DISCUSSION}

\section{Ultra Structural And Structural Analysis}

\section{Liver}

The liver of catfish without $\mathrm{FB}_{1}$ treatment (Control Group) showed organization pattern (Fig 1-1), similar with other the fishes described in the literature (Grizzle \& Rogers, 1985). In contrast, the treated livers (Groups II to IV) showed from slight to deep alterations, which were dose and exposure time dependent.

\section{Group II (1 mgFB $1 / \mathrm{kg}$. bw/day) \\ Day $7^{\text {th }}$}

The liver structure of sacrificed fish by LM, presented similarities to those of the Control Group, although the hepatocyte cords appeared vacuolated in some regions, characterized by the presence of clear and round intracitoplasmatic areas (Fig 1-2). An increase in the granular endoplasmic reticulum (GER) volume with enlarged cistern aggregates was also observed, suggesting an increase in the protein synthesis (Fig 1-3a) as confirmed by the overall protein test. The cell limits (cell membranes) were clearly visible.

\section{Day $14^{\text {th }}$}

The hepatocyte from some areas in the liver was increased in volume. Their nucleus also appeared enlarged and their nucleolus showed some contour alteration characterized by a "blurred" without delineated aspect, where filamentous expansions were projected. The nuclear contour was difficult to be clearly observed, suggesting loss of the membrane integrity (Fig 1-4). When compared with the Control or the $7^{\text {th }}$ collection animals (one week before), it was found that the GER volume was greatly increased, with annular lamel shaped cisterns often surrounding the mitochondria. The presence of the lysossomes and autophagic vacuoles was also observed, many of them found in the vicinity of mitochondria and surrounded by GER. Such a profile was an indication that they had been encapsulated and involved by lysossomic vacuoles (Fig. 1-4). Some images suggested the fusion occurring among them. It was observed in this animal Group (low $\mathrm{FB}_{1}$ conc.) that cytoplasm vacuolization became evident, possibly due to an autophagic process.

\footnotetext{
Day $21^{\text {st }}$

The TEM analysis showed retracted hepatocyte nucleus with many of them without nucleolus. GER was highly altered with some areas presenting a high concentration of expanded cisterns and others where GER displayed a discontinuous filamentous shape (Fig 1-3b). These features indicated the occurrence of an intense protein synthesis as a possible response of the cell to recover its homeostasis through lysossomic enzyme and membrane protein production. Some
} 
TEM images showed mitochondrial sets and the membrane coated GER, possibly autophagic vacuoles, as a cell reorganization attempt through an autophagic process. The LM tissue showed vacuolated areas and the presence of the macrophages containing lysossomes. It is important to point out that such a fact matches with other researchers data. Haschek et al. (1992), working on swine found similar hepatic profile (disorganization and hepatocyte necrosis) indicating that $\mathrm{FB}_{1}$ hepatotoxicity attacks mammals and fish in a similar way.

\section{Group III (5 mgFB $/ / \mathrm{kg}$. bw/day)}

\section{Day $7^{\text {th }}$}

As early as the $7^{\text {th }}$ day of treatment, the hepatic parenchyma appeared disaggregated with the high number of cavities. LM and TEM showed an accentuate anisokariosis, with some enlarged nuclei in contrastto others smaller ones when compared with Control (Figs 1-1; 2-1). The enlarged ones had globular aspect, the nucleolus could be easily located and the karyotec integrity was remained. In contrast, the retracted nucleus hepatocyte, apparently did not present a visible nucleolus. It had a diffuse nuclear membrane, sometimes presenting somewhere in the karyotec, which suggested extravasation of the nuclear content (Fig 2-1).

\section{Day $14^{\text {th }}$}

Many alterations in the cell membrane were observed, with difficulty for identifying cell limits, as the membrane appeared fragmented (Fig 2-2). In the TEM, the digestion of cell membrane fragment by the lysossomes was identified (Figs 23; 2-4). Gelderblom et al. (1996) observed the reduction of total lipids and free cholesterol by the $\mathrm{FB}_{1}$ radiolabelling hepatocyte from rats. As an integral component of the cell membranes, a decrease in free cholesterol may change the membrane fluidity. Both, the cholesterol and the sphingolipids contribute to cell functions, including transport between membranes and signal transduction (Harder and Simons, 1997).

\section{Day $21^{\text {st }}$}

Although, at previous stages, some mitochondria alterations were observed, at the end of this treatment almost all the mitochondria had roundish morphology, in contrast with oval or elongated shape in the Control. The mitochondria cristae presented degenerative alterations, fragmented in aspect or were even absent (Fig 2-3). It would be worth pointing out that the most resistant to disintegration mitochondrial element was the outer membrane, which maintained apparent integrity, even when most of inner elements had disappeared. Such data pointed that the composition and permeability between the mitochondrial membranes could act as cell stress sensor due to the quantity and accumulation of glycolipids and specific lipids. Acute accumulation of ceramids, directly or indirectly, deeply affected the mitochondrial functions (Alberts et al., 1999; Tomassini; Testi, 2002). Another relevant alteration was observed in the blood vases, mainly the capillars, which presented an enlarged diameter with reduced surrounding the conjunctive tissue. 

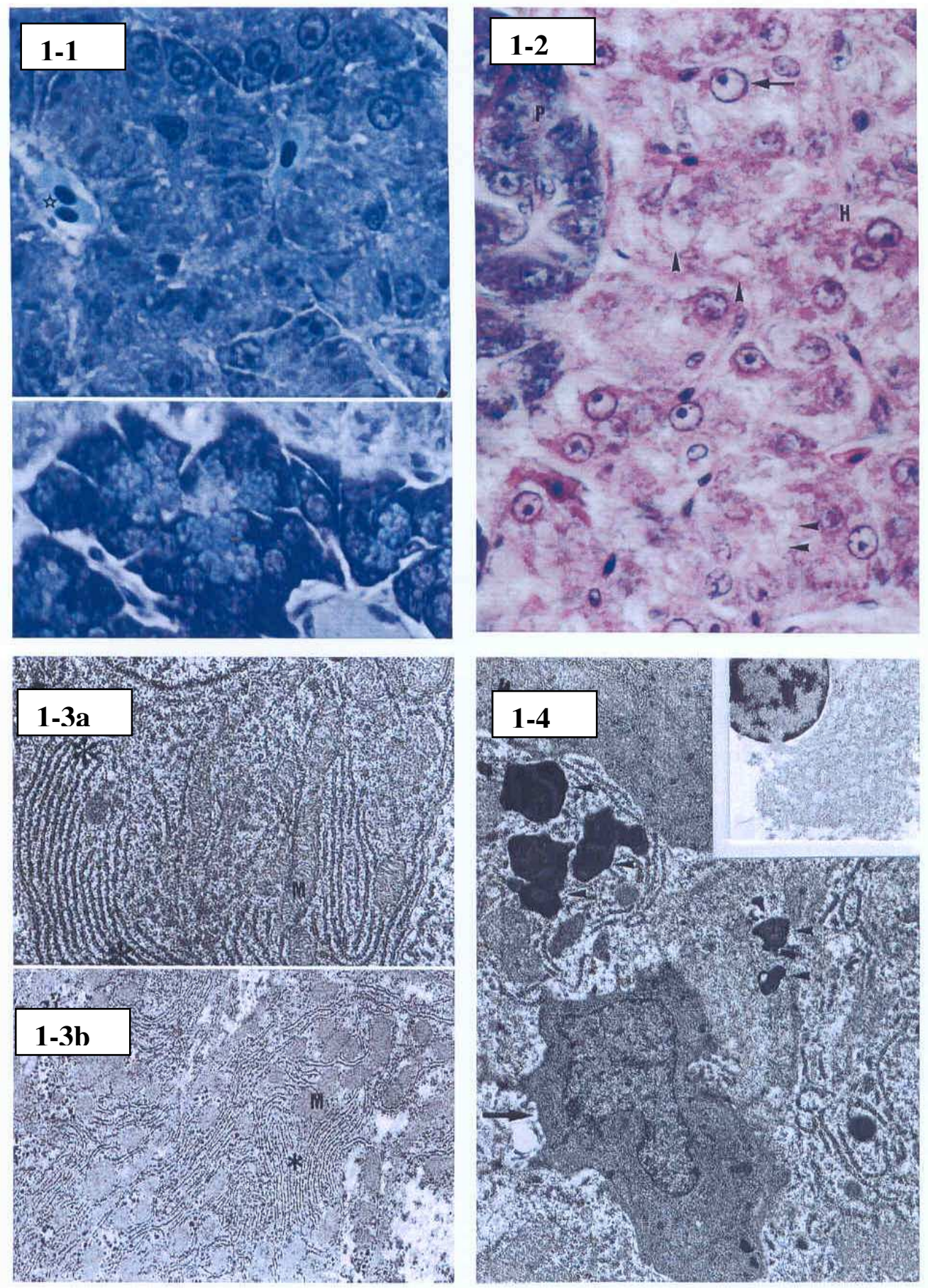

Figure 1 - [1-1] Light microscopy (LM): liver image of Control Group, showing the hepatocytes and veins (star); emphasis: structure of pancreas acini cells. Toluidin blue. 1000X. [1-2] LM: loss of integrity in hepatocyte cords with vacuolated round areas (arrow head); nucleus with enhanced volume (arrow); hepatocytes $(\mathrm{H})$; acini cells $(\mathrm{P})$; HE. 1000X. [1-3] Ultrastructure (US): (a) enhanced GER (asterisk); round mitochondria (M); nucleus (N). 13.000X. (b) delated cisterns of GER (asterisk); mitochondrias (M). 10.000X. [1-4] US: autophagic vacuoles (arrow head) in the hepatocyte citoplasm; Macrophages (arrow). 9.300X. Emphasis: loss of karyotec integrity and nucleus material. 7.400X 

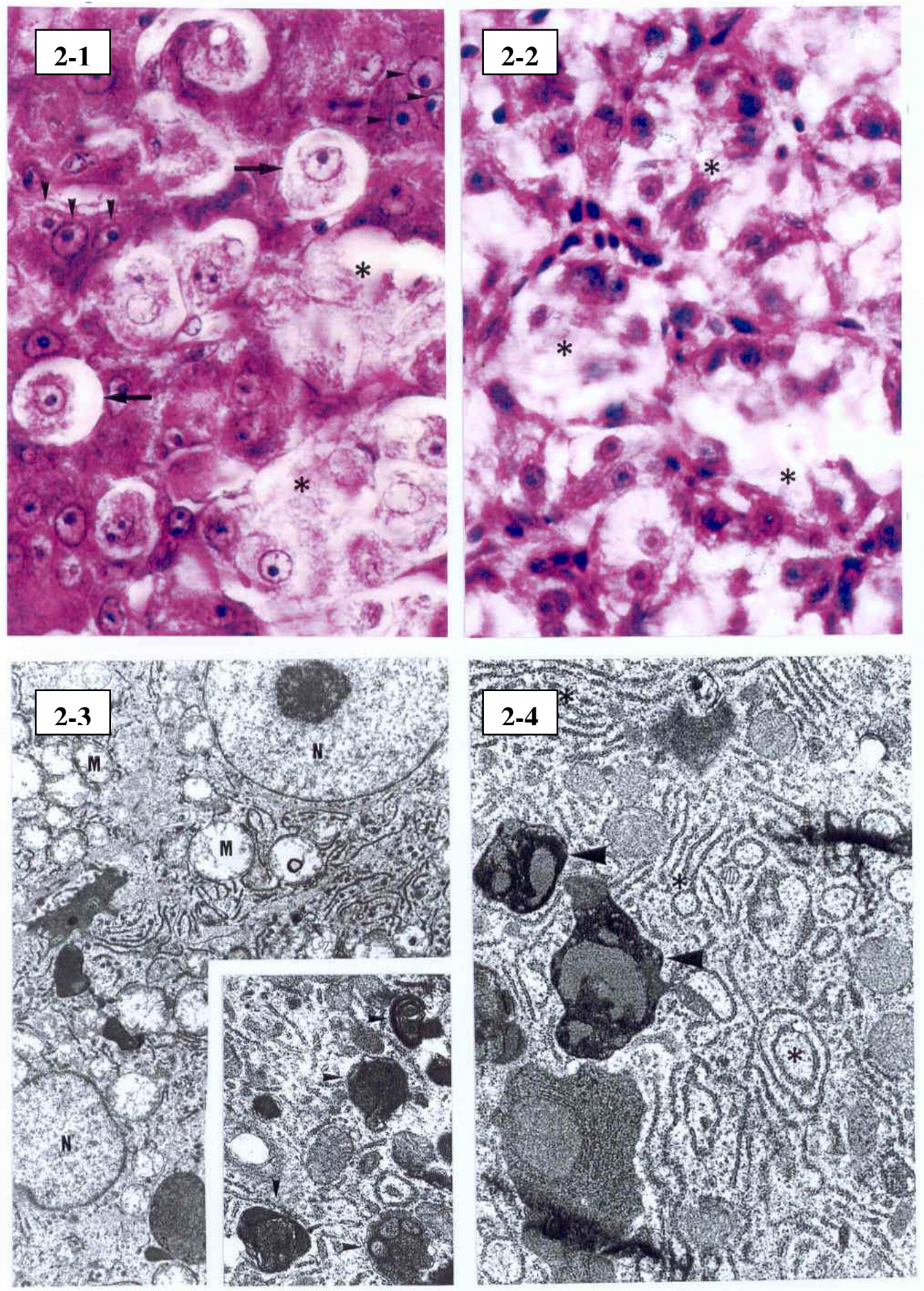

Figure 2 - [2-1] Light microscopy (LM): enlarged globular shaped hepatocytes with necrotic cytoplasm (arrow); necrotic areas (asterisk) and several size nuclei (arrow head). HE. 1000X. [2-2] LM: hepatic region with predominant areas of cellular necrosis (asterisk). HE. 1.000X. [2-3] Ultra structure (US): many round mitochondrias showing degeneration or absence of cristas (M) ; nucleus $(\mathrm{N})$. 6.500X; emphasis: autophagic vacuoles with organells in digestion process (arrow head). 12.000X. [2-4] US: autophagic vacuoles (arrow head) and profiles of GER with varied morphology (asterisk). 13.000X 


\section{Group IV (10 mgFB $1 /$ kg. bw/day)}

The Group IV livers presented an intense response for $\mathrm{FB}_{1}$ with an accentuate tissue disorganization, absence of the cell limits and intense cytoplasm vacuolization from the first sampling.

\section{Day $7^{\text {th }}$}

The TEM and LM analysis images suggested the occurrence of necrosis in some areas, characterized by the fully broken cells, or increased volume and swollen aspect. Macrophages and phagocytical vacuoles were also observed, indicating an intense macrophagical activity. (Figs 3-2; 3-3; 3-4; 4-4). These corroborated the data obtained in swine $\mathrm{FB}_{1}$ suggested by Haschek, et al. (1992) (oral and intravenous - IV). The authors found hepatocyte disorganization and necrosis, as well as the Kupffer cells with the multilamelar bodies. Lumlertdacha et al. (1995) findings matched to ours, as they also reported hepatocytes swollen and had central nuclei in the liver from the catfish treated with all the concentrations of FBs. Present data showed some hepatocyte nuclei with apparent integrity, indicating the maintenance of compartmentalization of the nuclear material by the means of the karyotec preservation. In contrast, other hepatocytes presented reduced nuclei, no visible nucleolus and broken up of chromatinic material, similar to those suggested in the literature as apoptotic process cells. Also it was possible to observe the margination of nuclear chromatin (Fig 3-2, 3-3). Disruption of sphingolipids metabolism and regulatory function are, therefore, likely to be critical for the cytotoxicity, apoptosis and carcinogenicity resulting from the fumonisin exposure. There is evidence that other factors are also involved, including the cytokine tumor necrosis factor $\alpha$ (TNF $\alpha$ ) (Voss et al., 2002). Bondy et al. (2000) found an increase in the apoptotic cell incidence in the rats liver treated with the $\mathrm{FB}_{1}$ and $\mathrm{FB}_{2}$ at 2,4 and $6^{\text {th }}$ days. Confirmation of apoptosis process was reached using DNA marked fragments. Therefore, the similarity between the present data with the relevant literature indicated strong evidence that numerous hepatocytes in the fish livers exposed to the FBs were selectively removed the apoptosis process.

\section{Day $14^{\text {th }}$}

The hepatocyte cytoplasm presented intense disorganization and vacuolization (Fig 4-1). In some regions of the liver, the necrosis prevailed, whereas in others, apoptosis was involved in the removal of hepatocytes as shown by nucleus shrinking (Fig 4-2). In regions with the necrosis, the enlarged and broken cells showed a spherical configuration. Its cytoplasm appeared partially empty, although the nucleus surrounded by some disorganized, slightly stained material, in the more central cell region could be observed. Nevertheless, even if the cell peripherical region presented the absence of normal cytosplasmatic elements, surrounding cells were maintained away, suggesting that some liquid kept the intracellular tonus.

\section{Day $21^{\text {st }}$}

The TEM revealed wide tissue disorganization due to high the $\mathrm{FB}_{1}$ concentration associated with the time of action on the fish liver. Through the analysis of the TEM of the cells that kept some integrity, it was found that although the GER could be observed all over the cytoplasm, parallel cistern aggregates could not be identified. Most structures were altered, and it was not possible to detect the presence of two distinct membranes. Eletron-dense myelin figures were well featured at this stage (Fig 4-3). The presence of the mitochondria showed the relative absence of the mitochondrial cristae, which were generally restricted to a small material waste in the mitochondrial periphery. The alterations previously described for all the collections $\left(7^{\text {th }}\right.$ and $14^{\text {th }}$ ), were at this stage much more accentuate, thus leading to a more intense and comprehensive disorganization framework. 

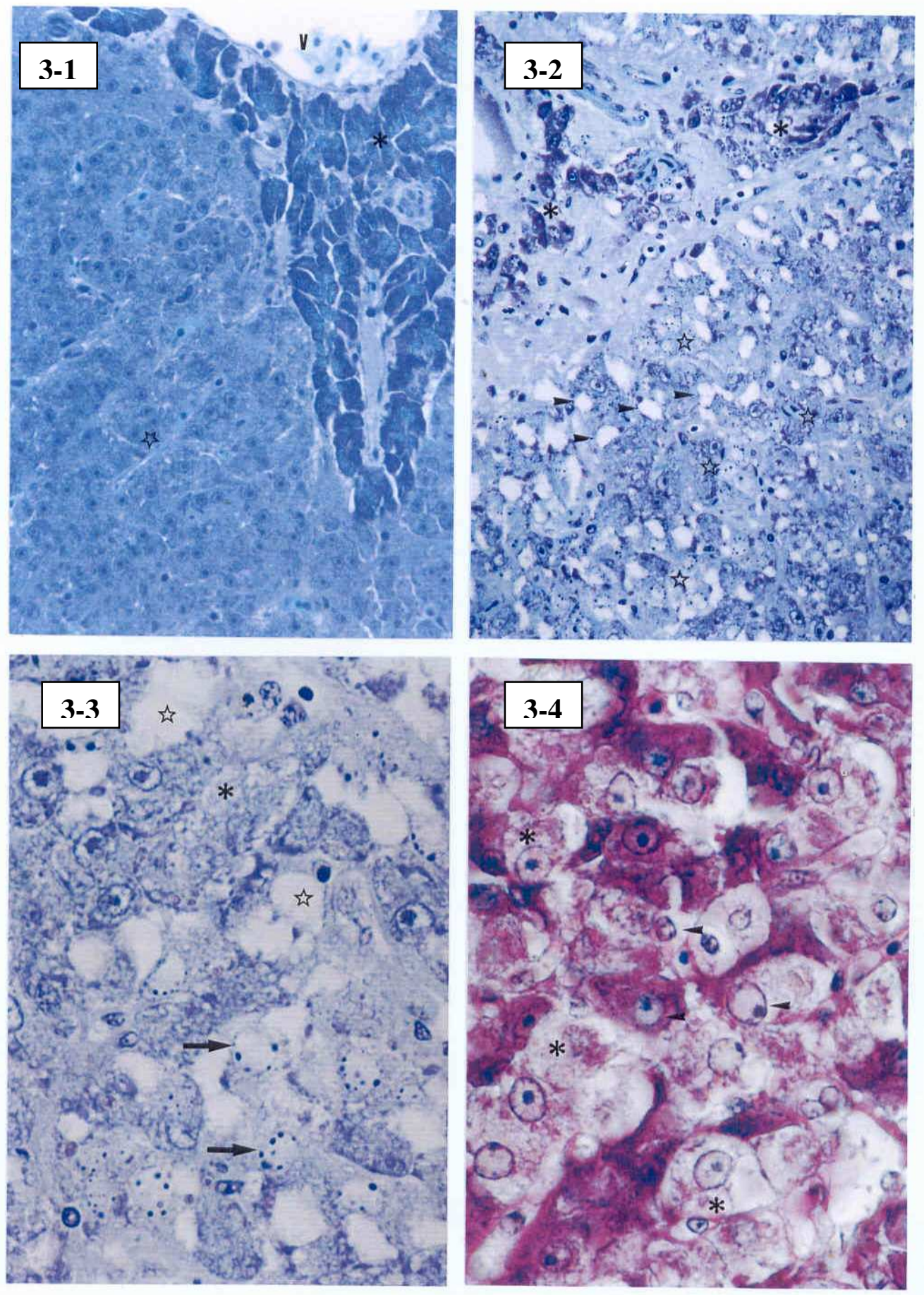

Figure 3 - [3-1] Light microscopy (LM): panoramic view of hepatopancreas of the Control Group; hepatocytes (star); acini cells (asterisk); vein (V). Toluidin blue (Tb). 400X. [3-2] LM: high hepatic tissue disorganization; retracted acini cells with vacuoles and nuclei disorganization (asterisk); hepatocytes vacuoled, some are presenting nuclear disintegration (apoptosis) (star); spaces resulting from cellular necrosis (arrow head). Tb. 400X. [3-3] ML: enlargement of Fig.[3-2]; emphasis: citoplasmatic vacuolization (asterisk); chromatin disintegration (apoptosis) (arrow); necrotic areas with citoplasmatic absence (star). Tb. 1000X. [3-4] ML: hepatocytes in necrotic process with high cellular nuclear volume (asterisk); nuclei with differtent volumes (arrow head). HE. 1000X 

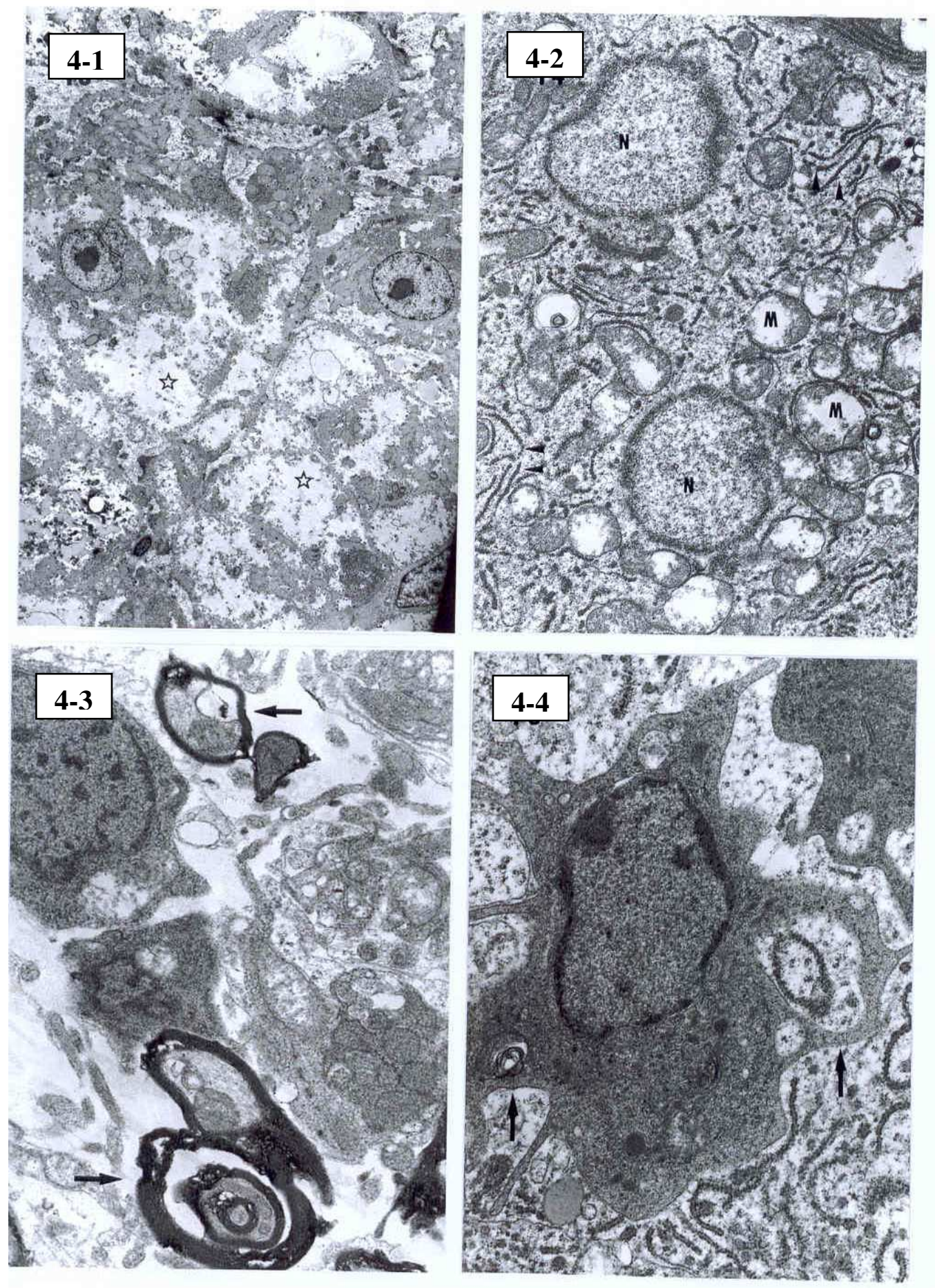

Figure 4 - [4-1] Ultra structure (US): hepatocytes with large areas of cytoplasmatic necrosis (star). 2.500X. [4-2] US: hepatocytes showing loss of definition of the nucleus contour $(\mathrm{N})$; mitochondrias with round morfology and cristas degeneration (M); GER (arrow head). 9.700X. [4-3] US: cytoplasm highly disorganizaded; emphasis: myelinic figures (arrrow). 13.000X. [4-4] US: macrophage with several pseudopodes and vacuoles holding organelles (arrow). 19.000X 


\section{Pancreatic Acini}

In the hepatic parenchyma from the Control Group, small aggregates of the acinous cell were observed surrounding the branches of the portal vein. In LM, such cells appeared pyramidal in shape, with strongly basophilic cytoplasm, mainly in the basal pole and apical accumulation of secretion granules that extend to $1 / 3$ of the cell baso-apical length. Its nucleus, with a visible nucleolus was located in the basal position (Fig 1-1; 3-1). On the other hand, in the fishes submitted to IP of the $\mathrm{FB}_{1}$ injection (Treated Groups), the acinous cells suffered progressive alterations with the cell retraction and shrinking of the cell aggregates. Small vacuoles appeared in the cytoplasm, conferring a spongeous aspect (Fig 3-2). At the end of the treatment, alterations occurred in the general organization of the acini, either at the cellular level or architecture. The cell degradation and the compactation was followed by the reduction in the volume. The presence of the secretion granules was not evidenced in the cytoplasm, which was further confirmed by the hystochemical test for the total proteins. An increase in the conjunctive tissue around the acini might be an indicative of the healing areas development (Fig 3-2). Similar data was obtained by Haschek et al. (1992) who found the acini cell degeneration in the porcine pancreas treated orally with the FBs. They reported shrunken acinous cells, with the condensed and hipereosinophilic cytoplasm in addition to a decreased number of the secretion granules.

\section{Histochemical Analysis}

\section{Total Protein (Comassie bright blue)}

The hystochemical analysis was carried out at the end of 21 days of the treatment. The hepatocyte cytoplasm of the Control Group presented a positive reaction that appeared as fine granulation thoroughly distributed. Nevertheless, in the Treated Groups, mainly through more powerful magnifying lenses $(17,000 \mathrm{x})$, it was possible to observe that all the cells presented a positive reaction; though some presented more intense reaction than the others. This provided a variety of irregular shapes in the cells with dark spots on them. The cytoplasm acquired a lacelike aspect, which was derived from the cytoplasmatic structures similar to vacuoles. The nuclear material features were an irregular contour dark blue spot, highly undefined, not enabling thus, to estimate the nuclear envelope limits. In some cells, the nucleolus could even be observed. No positive reaction for the total proteins was observed at the end of the treatment in the pancreatic acini. In the Control Group, this test was highly positive for the pancreatic acinous cells with an evidence of great number of rough granules intensively stained in blue.

\section{Glycogen (PAS-amylase):}

There was a low reactiveness for glycogen in the hepatocytes of the Treated Groups, while in the Control Group the positive reaction was characterized by the purple granulation in the hepatocyte cytoplasm. These results corroborated to Bondy et al. (1995; 2000), who found that in the liver sections from the rats of the Controls, stained with the PAS, there was a generalized staining of hepatocyte cytoplasm while in the kidney from the Treated rats, the PAS positive cells were limited to some groups, or isolated and contained fewer granules, indicating a reduced storage of the glycogen in the liver. Similarly, Haschek et al. (1992) working on swine, observed that treated animal hepatocytes presented some reduction in the glycogen amounts.

\section{Lipid (Sudan Black)}

Stain marked the Treated Groups animal hepatocytes positively, revealing irregular and coarse lipid material aggregate unevenly distributed through the hepatic parenchyma. In contrast, the Control Group showed regular distribution of lipids in the hepatic cells that was shown by the presence of thin dark cytoplasmatic granulation.

\section{CONCLUSIONS}

This study showed intracellular organelles alterations particularly in the nucleus, nucleolus, GER and mitochondria mediated by the $\mathrm{FB}_{1}$ doses in the catfish. Alterations and disruption in all the membranes (complex membranous) to the cellular level were detected, as well as the karyotec constituents and organelles cytoplasmic membranes such as mitochondria and GER. The occurrence of the processes involved in the necrosis and the 
apoptosis was also detected. The necrosis was demonstrated by the cellular swolling, loss of the cellular membrane and posterior disintegration. The apoptosis was observed as the cytoplasm contraction and the chromatin formed concentrated masses at the edge of the nucleus. There was strong evidence that the numerous hepatocytes in the liver from the fish under the toxic dose of the FBs were selectively removed by the apoptosis process. Data also indicated further complementary morphological and histochemical studies involving other organs, if the observed alterations at the cellular level in the liver, could also occur in different systems and tissues.

\section{RESUMO}

Os efeitos histopatológicos da fumonisina $B_{1}$ (FB1) foram avaliados quando a toxina foi aplicada intraperitoneal (IP) em bagre (Ictalurus punctatus). Os peixes foram divididos em 4 Grupos, sendo que os Grupos II, III e IV foram tratados com $\mathrm{FB}_{1}$ em injeções IP nas concentrações de $1 ; 5$ e $10 \mathrm{mg} / \mathrm{kg}$ p.c./dia, respectivamente, durante 21 dias. No $7^{\circ}, 14^{\circ}$ e $21^{\circ}$ dia de tratamento, amostras de peixe de cada Grupo foram sacrificadas. Os figados foram analisados histopatologicamente por microscopia de luz e de transmissão eletrônica. Desde o dia 7 de coleta, os fígados apresentaram alterações em diversas organelas, principalmente no retículo endoplasmático, citoplasma, núcleo e nucléolo mediadas pelas doses de $\mathrm{FB}_{1}$. A ocorrência de processos envolvidos em necrose e apoptose foi detectada. A níveis mais elevados, os fígados apresentaram resposta intensa para $\mathrm{FB}_{1}$, com acentuada desorganização dos tecidos, ausência de limites das células e intensa vacuolização do citoplasma. A análise por imagem revelou ocorrência de necrose em determinadas áreas, caracterizada pela presença de células totalmente quebradas ou edemaciadas. A apoptose foi observada pela contração do citoplasma e formação de massas de cromatina concentradas nas extremidades do núcleo. Há uma forte evidência de que numerosos hepatócitos no fígado do peixe sob doses tóxicas de FBs sejam seletivamente removidos pelo processo de apoptose.

\section{REFERENCES}

Abado-Becognee, K.; Mobio, T.A.; Ennamany, R.; Fleurat-Lessard, F.; Shier, W.T.; Badria, F.; Creppy, E.E. (1998), Citotoxicity of $\mathrm{FB}_{1}$ : implication of lipid peroxidation and inhibition of protein and DNA syntheses. Archives Toxicology, 72, 233-236.

Alberts, B.; Bray, D.; Lewis, J.; Raff, M.; Roberts, K.; Watson, J.D. (1997), Biologia Molecular da Célula. $3^{\mathrm{a}}$ ed., P.A. Editora Artes Médicas, pp.143.

Bolger, M.; Coker, R. D.; Dinovi, M.; Gaylor, D.; Geldeblom, W.; Olsen, M.; Paster, N.; Riley, R.T.; Shephard, G.; Spijers, G. J. A. (2001), Fumonisins: Safety evaluation of certain mycotoxin in food. In: International Programme on Chemical Safety WHO. Geneva. FAO Food and Nutrition Paper 74, WHO Food Additives Series, 47, 103-279.

Bondy, G.; Suzuki, C.; Barker, M.; Armstrong, C.; Fernie, S.; Hierlihy, L.; Rowsell, P.; Muller, R. (1995), Toxicity of $\mathrm{FB}_{1}$ administered intraperitoneally to male sprague-dawley rats. Food and Chemical Toxicology, 33, 8, 653-665.

Bondy, G.S.; Barker, M.G.; Lombaert, G.A.; Armstrong, C.L.; Fernie, S.M.; Gurofsky, S.; Huzel, V.; Savard, M.E.; Curran, H.A. (2000), A comparison of clinical, histopathological and cell-cycle markers in rats receiving the fungal toxins $\mathrm{FB}_{1}$ or $\mathrm{FB}_{2}$ by intraperitoneal injection. Food and Chemical Toxicology, 38, 873-886.

Brancroft, I.D.; Stevens, A.; Turner, D.R. (1990), Theory and Practice of Histological Techniques. Churchill Livingstone. Edinburgh, pp. 254.

Domijan, A.M.; Peraica, M.; Jurjevic, Z.; Ivic, D. 2005, FB1, FB2, ZON and OTA contamination of maize in Croatia. Food Additives and Contaminants 22, 7 , 677-680.

Gelderblom, W.C.A.; Kriek, N.P.J.; Marasas, W.F.O.; Thiel, P.G. (1991), Toxicity and carcinogenicity of $F$. moniliforme metabolite, fumonisin $\mathrm{B}_{1}$ in rats. Carcinogenesis, 12, 1247-1251.

Gelderblom, W.C.A.; Smuts, C.M.; Abel, S.; Snyman, S.D.; Cawood, M.E.; Van Der Westhuizen, L.; Swanevelder, S. (1996), Effect of $\mathrm{FB}_{1}$ on protein and lipid synthesis in primary rat hepatocytes. Food and Chemical Toxicology, 34, 361-369.

Goel, S.; Lens, S.D.; Lumlertdacha, S.; Lovell, R.T.; Shelby, R.A.; Li, M.; Riley, R.T.; Kemppainen, B.W. (1994), Sphingolipid levels in catfish consuming $F$. moniliforme corn culture material with fumonisins. Aquatical Toxicology, 30, 285-294.

Grizzle, J.M.; Rogers, W.A. (1985), Anatomy and Histology of the Channel Catfish. $3^{\text {rd }} \mathrm{ed}$, Ed. Craftmaster Printer Inc. Alabama, USA, pp. 94.

Harder, T.; Simons, K. (1997), Caveolae, DIGs and the dynamic of sphingolipid-cholesterol microdomains. Current Opinion in Cell Biology, 9, 534-542. 
Harrison, L.R.; Colvin, B.M.; Greene, J.T.; Newman, L.E.; Cole, J.R. Jr. (1990), Pulmonary edema and hydrothorax in swine produced by fumonisin $\mathrm{B}_{1}$, a toxic metabolite of $F$. moniliforme. Journal of Veterinary Diagnostic Investigation, 2, 217-221.

Haschek, W.M.; Motelin, G.; Ness, D.K.; Harlin, K.S.; Hall, W.F.; Vesonder, R.F.; Peterson, R.E.; Bealey, V.R. (1992), Characterization of fumonisin toxicity in orally and intravenously dosed swine. Mycopathologia, 117, 83-96.

Howard, P.C.; Eppley, R.M.; Stack, M.E.; Warbritton, A.; Voss, K.A.; Lorentzen, R. J.; Kovack, R.; Bucci, T.J. (1999), Carcinogenicity of $\mathrm{FB}_{1}$ in a two-year bioassay with Fischer 344 Rats and $\mathrm{B}_{6 \mathrm{C}} 3 \mathrm{~F}_{1}$ Mice. Proceedings of International Symposium of Mycotoxicoly'99. Mycotoxins Supplement, 45-54.

Lumlertdacha, S.; Lovell, R.T.; Shelby, R.A.; Lenz, S.D.; Kemppainen, B.W. (1995), Growth, hematology and histopathology of channel catfish, Ictalurus punctatus, fed toxins from $F$. moniliforme. Aquaculture, 130, 201-218.

Li, M.H.; Raverty, S. A.; Robinson, E.H. (1994), Effects of dietary mycotoxins produced by $F$. moniliforme on catfish Ictalurus punctatus. Journal of World Aquaculture Society, 25, 4, 512-516.

Lim, C.W., Parker, H.M., Vesonder, R.F., Haschek, W.M. (1996), Intravenous $\mathrm{FB}_{1}$ induces cell proliferation and apoptosis in the rat. Natural Toxins, 4, 34-41.

Mobio, T.A.; Baudrimont, I.; Sanni, A.; Shier, T.W.; Sabourneau, D.; Dano, S.D.; Ueno, Y.; Steyn, P.S.; Creppy, E.E. (2000), Prevention of vitamin E of DNA fragmentation and apoptosis induced by $\mathrm{FB}_{1}$ in $\mathrm{C} 6$ glioma cells. Archives Toxicology, 74, 112-119.

Nikiemg, P.N.; Worrillow, L.; Traore, A.S.; Wild, C.P.; Turner, P.C. (2005), Fumonisin contamination of mayse in Burkina Faso, West Africa. J. of Food Additives and Contaminants, 21, 9, 865-870.

Norred, W.P.; Voss, K.A. (1994), Toxicity and role of fumonisins in animal diseases and human EC. Journal of Food Protection, 57, 6, 522-527.

Pearse, A.G.E. (1985), Histochemistry Theoretical and Applied. In: Analytic Technology. Vol 2, $4^{\text {th }}$ Ed. Churchill Livingstone. New York, pp. 124.

Pepeljnjak, S.; Petrinec, Z.; Drca, S.; Segvic, M.; Ferencic, Z.; Jurisic, B. (2000), Evaluation of $\mathrm{FB}_{1}$ toxicity to carp (Cyprinus carpio L.). Paper presented at X International IUPAC Symposium on Mycotoxins and Phycotoxins, 21-25 May, Guaruja, SP, Brazil.
Riley, R.T.; Gelineau-Van Waes, J.; Voss, K.A.; Sharma, R.P.; Haschek, W.M.; Constable, P.D. 2004. Toxicology of fumonisins and neural tubes defects. Paper presented at XI Internacional IUPAC Symposium on Mycotoxins and Phycotoxins, 17 - 21 May, Bethesda, MA, USA, O-20:32.

Scaf, R.M.C.; Scussel, V.M. (2004), Fumonisin $B_{1}$ and $\mathrm{B}_{2}$ in corn-based products commercialized in Santa Ctarina State - Southern Brazil Brazilian Archives of Biology and Technology, 47:911-919.

Scussel, V.M.; Costa, L.L.F.; Perez, M. (2004), Fumonisin $\mathrm{B}_{1}$ and $\mathrm{B}_{2}$ in catfish (Icatalurus punctatus) feed and ingredients. XI International IUPAC Symposium on Mycotoxins and Phycotoxins, 17-21 May, Bethesda, MA, USA, B-39:76.

Scott, P.M. (1993), Fumonisins. International Journal of Food Microbiology, 18, 4, 257-270.

Tolleson, W.H.; Couch, L.H.; Melchior Jr, W.B.; Jenkins, G.R.; Muskhelishvili, L.; Mcgarrity, L.J.; Domon, O.; Morris, S.M.; Howard, P.C. (1999), FB induces apoptosis in cultured keratinocytes through sphinganine accumulation e ceramide depletion. International Journal of Oncology, 14, 833-843.

Tomassini B., Testi, R. (2002), Mitochondria as sensors of sphingolipids. Biochimie, 84, 123-129.

Voss, K. A.; Howard, P.C.; Riley, R.; Sharma, R.P.; Bucci, T.J.; Lorentzen, R.J. (2002), Carcinogenicity and mechanism of action of $\mathrm{FB}_{1}$ : mycotoxin produced by $F$. moniliforme ( $F$. verticillioides), Cancer Detection and Prevention, 26, 1-9.

Wang, E.; Norred, W.P.; Bacon,Cw.; Riley, R.T.; Merril, A.H. Jr. (1991), Inhibition of sphingolipid biosynthesis by fumonisin. Implications for diseases associated with $F$. moniliforme. Journal of Biological Chemistry, 266, 14486-14490.

Westhuizen, L.; Shephard, G.S.; Scussel, V.M.; Costa, L.L.F.; Vismer, H.F.; Rheeder, J.P.; Marasas, W.F.O. (2003), Fumonisin contamination and Fusarium incidence in corn from SC, Brazil, Journal of Agricultural and Food Chemmistry, 51, 18, 55745578.

Received: November 11, 2005; Revised: December 11, 2006; Accepted: June 22, 2007. 